\title{
Earth's Amphibious Transformation: Tange Kenzo, Buckminster Fuller, and marine urbanization in global environmental thought (1950s-present)
}

\author{
Stefan Huebner* (1) \\ Asia Research Institute, National University of Singapore \\ *Email: arihust@nus.edu.sg
}

(Received 11 May 2020; revised 19 May 2021; accepted 24 May 2021)

\begin{abstract}
Climate change and rising sea levels, which threaten many Asian and other coastal cities, have returned the question of adaptation to unstable marine surfaces to the global discussions about urbanization, as was illustrated by a recent United Nations (UN) roundtable. As de facto counterproposals to hydroelectric dams and similar regional development projects, floating or elevated structures reject land reclamation and terrestrialization processes. Consequently, the rapidly growing number of offshore structures, which often constitute unconventional settlements, have contributed to an amphibious transformation of Earth's surface in the course of the twentieth and early twenty-first centuries. This amphibious transformation meant that both terrestrial and aquatic places have turned into human habitats. This article asks how and why today's leading environmental-political strand in large-scale marine urbanization emerged from the waters of Tokyo Bay. It investigates Japanese star architect Tange Kenzō's 'Plan for Tokyo 1960' (1961) and world-renowned American designer R. Buckminster Fuller's floating design called 'Tetrahedronal City' (1966). Emphasizing the important role that Asian cities have played in shaping global urbanization ideas and practices, Tokyo Bay became a node in the global cybernetics revolution that moved urban design into the information age. Tange's and Fuller's evolution-inspired cybernetic designs used the post-war communication technology revolution to replicate, through artificial communication networks, the biological communication systems that enable organisms to interact with their environments. Applying communication technology to recreate, in floating or elevated structures, the biological processes of growth, adaptation, mobility, and autonomy became the central environmental-political strand for large-scale marine urbanization and reducing its ecological footprint.
\end{abstract}

(C) The Author(s), 2021. Published by Cambridge University Press. This is an Open Access article, distributed under the terms of the Creative Commons Attribution licence (http://creativecommons.org/licenses/by/4.0), which permits unrestricted re- use, distribution and reproduction, provided the original article is properly cited. 


\section{Introduction}

Earth's surface is experiencing what I call an 'amphibious transformation'. On 3 April 2019, United Nations (UN) Deputy Secretary-General Amina Mohammed addressed several of the twenty-first century's environmental challenges at a high-level roundtable at the UN headquarters in New York City: 'Floating cities are a means of ensuring climate resilience, as buildings can rise along with the sea. And when entire floating communities are designed from scratch, they can be designed as climate-neutral from the onset.' ${ }^{1}$ In her speech at this first roundtable on 'sustainable floating cities', Mohammed summed up several ideas on how to adapt to these planetary challenges. In terms of climate change resilience, floating structures not only rise with the sea level but are also hardly affected by intensifying floods. Moreover, designing a 'floating city' or settlement from scratch means that there is potential to create an environmentally sustainable structure using renewable energy generation and electric-powered public transportation systems. In the context of climate change, environmental degradation, and rising sea levels, which have affected many Asian and other coastal cities, such ideas and practices of floating structures have been gaining global significance. After all, organizations such as the Global Commission on Adaptation or the Intergovernmental Panel on Climate Change (IPCC) have emphasized that climate change mitigation alone is no longer sufficient, resulting in a need for both mitigation and adaptation. ${ }^{2}$ There are various, often incompatible, environmental-political approaches to such adaptation. However, the currently dominant, technology-driven ecomodernist approach that shapes large-scale marine urbanization, as was the case at the UN roundtable, intellectually emerged from the waters of Tokyo Bay.

This article's main question is how and why cybernetics-based designs for Tokyo Bay from the 1960s created the ecomodernist approach in large-scale marine urbanization. The main focus is on Japanese star architect Tange Kenzō (1913-2005) and his university laboratory's (Tange Lab) 'Plan for Tokyo 1960' (hereafter 'the Plan'), released in very early 1961, and on world-renowned American designer R. Buckminster Fuller's (1895-1983) floating design called 'Tetrahedronal City', first proposed in 1966. Tange and Fuller mutually inspired each other's cybernetics-based megastructure designs during the 1960s. They knew each other personally and spent substantial time together at the week-long 'Delos Symposium on Human Settlements' in July 1966. Showing the connections between Tange and Fuller, putting both of

\footnotetext{
${ }^{1}$ United Nations, 'Sustainable Floating Cities Can Offer Solutions to Climate Change Threats Facing Urban Areas, Deputy Secretary-General Tells First High-Level Meeting', https://www.un. org/press/en/2019/dsgsm1269.doc.htm, [accessed 15 June 2021].

2 'GCA Will Soon Be Working in the Largest Floating Office in the World', https://www.youtube. com/watch?v=TOkA2e6bYy4, [accessed 15 June 2021]; Michael Oppenheimer et al., 'Sea Level Rise and Implications for Low-Lying Islands, Coasts and Communities', in IPCC Special Report on the Ocean and Cryosphere in a Changing Climate, (eds) Hans-Otto Pörtner et al. (Geneva: IPCC, 2019), pp. 321-445; Urban Climate Change Research Network et al., The Future We Don't Want. How Climate Change Could Impact the World's Greatest Cities. Technical Report (New York: Urban Climate Change Research Network, 2018).
} 
their Tokyo Bay designs into the global perspective of Earth's amphibious transformation, and evaluating their intellectual legacy in the context of climate change, environmental degradation, and related threats to Asian and other coastal cities broadens the view beyond the Japanese nation-state box which, as I will show, has usually shaped related research.

What I call the amphibious transformation of Earth's surface continues to move urbanization onto the sea. Other scholars have talked about the planetary reach of urbanization, in the sense that the resource-hunger of cities has 'extended' urbanization into various hinterlands, including the ocean, through resource extraction. ${ }^{3}$ However, this article focuses on designs for actual, if unconventional, settlements. After all, through the amphibious transformation, both terrestrial places and marine surfaces have turned into human habitats. I call this transformation amphibious, since it did not result in a change of the physical properties of marine regions, as would have happened in the case of terrestrialization through land reclamation. In contrast to largely two-dimensional, solid ground on land, such marine places remained volumetric (meaning three-dimensional), liquid, and unstable. This article therefore expands on the physical properties of marine regions, illustrating the role that environmental conditions played in the development of dynamic and adaptive practices of marine urbanization and its architecture. ${ }^{4}$ Since the midtwentieth century, a rapidly growing number of human-built structures have been residing on marine surfaces, turning these places into a human habitat. Marine regions located several miles offshore of coastal cities are not 'distant' anymore, except in land-centric ontologies, and due to such biases need to be addressed as places of urbanization. For amphibious and floating architects and designers, spatial practices changed when communication networks turned empty marine surfaces into places associated with human settlement. Where once only individual ships could signal each other upon meeting, radio and, later, satellite technology connected marine surfaces to more advanced terrestrial communication systems, eliminating the spatial divide between them. I call it a transformation because the growth of global communication networks, including the transportation and energy networks operated by them, are a central reason for approaching marine surfaces as part of an amphibious

\footnotetext{
${ }^{3}$ Neil Brenner, New Urban Spaces. Urban Theory and the Scale Question (Oxford: Oxford University Press); Nancy Couling, 'Formats of Extended Urbanisation in Ocean Space', in Emerging Urban Spaces. A Planetary Perspective, (eds) Philipp Horn, Paola Alfaro d'Alencon and Ana Claudia Duarte Cardos (Cham: Springer International, 2018), pp. 149-176.

${ }^{4}$ Demands for a stronger focus on oceanic spaces and 'wet ontologies' have become louder in historical science, geography, literary studies, etc. Such new approaches nevertheless lack a focus on urbanization. See David Armitage, Alison Bashford and Sujit Sivasundaram, 'Introduction: Writing World Oceanic Histories', in Oceanic Histories, (eds) David Armitage, Alison Bashford and Sujit Sivasundaram (Cambridge: Cambridge University Press, 2017), pp. 1-28; Elisabeth Deloughrey, 'Submarine Futures of the Anthropocene', Comparative Literature 69, no. 1 (2017), pp. 32-44; Philip Steinberg and Kimberley Peters, 'Wet Ontologies, Fluid Spaces: Giving Depth to Volume through Oceanic Thinking', Environment and Planning D 33, no. 2 (2015), pp. 247-264.
} 
ontology. Such communication networks create what in this article is understood as urbanization, meaning not the concentration of an (arbitrarily defined) number of people in a certain area but access to networks that realize global urban connectivity. ${ }^{5}$ Thousands of floating or fixed oil and gas platforms have enabled humans to live permanently offshore and to be connected to global communication networks. Other floating or fixed structures include harbour facilities, liquefied natural gas (LNG) terminals, helipads, space rocket launch platforms, oil storages, bridges, mariculture (marine organism farming) facilities, military installations, wind turbines, nuclear power plants, solar panels, breakwaters, dairy farms, gardens, hotels, and mass-produced hightech floating homes. ${ }^{6}$ These are accompanied by cruise ships, aircraft carriers, factory ships for freezing and processing fish and whales, and so on-all inhabiting marine and other aquatic surfaces.

Before the twentieth century became dominated by what I call a 'terrestrial mindset', humans adapting to amphibious habitats was not uncommon. A growing historical and anthropological literature on Asian river deltas showed how the regular presence of water and related environmental conditions shaped the awareness of people and their settlement practices. For example, in Thailand's Chao Phraya river delta, perennial floods resulted in amphibious settlement practices like stilted houses or raft houses, the latter floating when the water arrived. In terms of adapted agriculture, in some regions floating rice, with fast-growing stems, survived water level rises of more than three metres. ${ }^{7}$ Other studies addressed, for example, ebune (from Japan's Seto Inland Sea) and other 'boat people' who for centuries adapted themselves to life on boats. Urban studies showed how even during the twentieth century such boat dwellers created unplanned forms of urbanization in Tokyo and other cities. What many of these studies emphasized is that terrestrial authorities discriminated against their way of life, tried to remove them, and

\footnotetext{
${ }^{5}$ See, for example, Nick Dunn, 'Infrastructural Urbanism: Ecologies and Technologies of Multi-Layered Landscapes', Spaces and Flows 1, no. 1 (2011), pp. 87-96; Gabriël Dupuy, Urban Networks-Network Urbanism (Amsterdam: Techne Press, 2008).

${ }^{6}$ For recent overviews, see C. M. Wang, Soon Heng Lim and Zhi Yung Tay (eds), WCFS2019: Proceedings of the World Conference on Floating Solutions (Singapore: Springer Nature, 2020); Katherine Dafforn et al., 'Marine Urbanization: An Ecological Framework for Designing Multifunctional Artificial Structures', Frontiers in Ecology and the Environment 13, no. 2 (2015), pp. 82-90; Edmund Penning-Rowsell, 'Floating Architecture in the Landscape: Climate Change Adaptation Ideas, Opportunities and Challenges', Landscape Research 45, no. 4 (2020), pp. 395-411; 'Welcome to Urban Rigger', https://www.urbanrigger.com/, [accessed 15 June 2021]; 'Floating Farm', https://floatingfarm.nl/de-farm/, [accessed 15 June 2021]; 'Welcome to ABC Arkenbouw', https://www.hollandhouseboats.com/about-abc/binnenkijken, [accessed 15 June 2021]. See also the amphibious and floating architecture-related TED Talks at https://www.ted.com/, [accessed 15 June 2021].

${ }^{7}$ David Biggs, Quagmire: Nation-Building and Nature in the Mekong Delta (Seattle: University of Washington Press, 2010); Casper Bruun Jensen and Atsuro Morita, 'Deltas in Crisis: From Systems to Sophisticated Conjunctions', Sustainability 12, no. 4 (2020), p. 1322; Atsuro Morita, 'Infrastructuring Amphibious Space: The Interplay of Aquatic and Terrestrial Infrastructures in the Chao Phraya Delta in Thailand', Science as Culture 25, no. 1 (2016), pp. 117-140.
} 
associated floating or amphibious settlement practices with low-tech or primitive living conditions. ${ }^{8}$

I analyse the amphibious transformation of Earth's surface from the perspective of the cybernetics boom in urban design, which radically changed design ideas and turned Tokyo Bay into the birthplace of ecomodernist marine urbanization. In that sense, I expand on the urban studies publications that have emphasized the important role played by Asian cities in shaping both regional and global urbanization trends. ${ }^{9}$ In this article, I see Fuller and Tange as leading transnational figures in the urban design-related branch of the global cybernetics boom, which focused on blurring borders between biological and artificial systems of communication and control. This cybernetics boom was caused and driven by the communication technology revolution that has taken place since the 1940s. Cybernetics is regularly described as the dawn of the 'Information Age' and evolved from MIT mathematician Norbert Wiener's eponymous book, published in 1948, even though its ecological models were increasingly overshadowed by the information-conduit model of IT (information technology). ${ }^{10}$ Initially focusing on modelling how the very first electronic digital computers or 'electronic brains' operated, cyberneticists considered artificial communication systems to replicate biological ones: operating through feedback loops, such biological communication systems (like the neural networks of brains) enable and coordinate an organism's interaction with its environment, retrieving of and processing of information, reactions based on achieving a certain task or goal, followed by renewed environmental interaction. This new way of modelling rapidly spread across academic disciplines, including architecture, where it resulted in novel urban designs centred on communication systems. ${ }^{11}$

This article argues that Tange Lab and Fuller, applying their cybernetics models, designed artificial communication systems that, by replicating biological processes, served to expand urban design practices to marine surfaces by eliminating the spatial divide between them and terrestrial places. The communication technology revolution allowed Tange Lab and Fuller to design marine urbanization structures that hosted such communication systems consisting of communication, transportation, and energy networks. For example, on land and at sea, human nervous systems (meaning biological communication systems) were extended-or connected to each other-through artificial networks

\footnotetext{
${ }^{8}$ Toshiko Yamamoto, "Ebune" no kenkyūshi [History of Research on "ebune"]', Komazawa daigaku kyōikugaku kenkyū ronshū 32 (2016), pp. 107-135; David E. Sopher, The Sea Nomads. A Study of the Maritime Boat People of Southeast Asia (Singapore: National Museum, 1977); Eugene N. Anderson, Floating World Lost: A Hong Kong Fishing Community (New Orleans: University Press of the South, 2007).

${ }^{9}$ See, for example, Tim Bunnell and Daniel P. S. Goh (eds), Urban Asias. Essays on Futurity Past and Present (Berlin: Jovis, 2018); Ananya Roy and Aihwa Ong (eds), Worlding Cities. Asian Experiments and the Art of Being Global (Chichester: Wiley-Blackwell, 2011).

${ }^{10}$ Norbert Wiener, Cybernetics: Or Control and Communication in the Animal and the Machine (Cambridge, MA: MIT Press, 1948).

${ }^{11}$ On the early cybernetics boom, see Ronald R. Kline, The Cybernetics Moment: Or Why We Call Our Age the Information Age (Baltimore: Johns Hopkins University Press, 2015), pp. 68-101.
} 
created by computers, telephones, telex, TV, CCTV, radio, as well as transportation devices. Consequently, this article also argues that Tange's and Fuller's biomimetic model of communication and control aimed at using communication network technology to replicate, in floating or elevated structures, the biological processes of growth, adaptation, mobility, and autonomy (meaning the design's self-sufficiency), which then became the central environmentalpolitical approach for moving urbanization offshore and reducing its ecological footprint. The cybernetic designs served to limit Tokyo's horizontal urban sprawl, partially removed urbanization from terrestrial space, and maximized the lifespan of modular elements, which all correlated with a reduced attendant pressure on ecosystems. As this article emphasizes, current ecomodernist ideas and practices in marine urbanization go back directly to Tange's and Fuller's contributions to the cybernetics boom-even though the bio-informational language has disappeared. Ecomodernism is one of a number of environmental-philosophical 'schools' of thought. Others focus, for example, on degrowth strategies or harmonization with nature. While the 'Ecomodernist Manifesto' of 2015 was signed by just 18 scholars, the ideas and practices of a much larger number of politicians, designers, ecologists, and others can be associated with ecomodernism or correspond to it to some degree. Ecomodernism's main goal is to apply and advance ecologically largely or fully autonomous technologies to decouple continuous human development from large environmental impacts. Among such decoupling approaches, which thus aim at separating human activities and nature from each other instead of advocating harmony between them, are high-density urbanization instead of horizontal urban sprawl, zero-carbon nuclear and solar energy generation instead of fossil fuels, mariculture instead of capture fisheries, and desalination instead of freshwater exploitation. ${ }^{12}$

Analysing and re-evaluating Tange Lab's and Fuller's Tokyo Bay projects is important, since previous scholarship focused only on Tange and his mentorship of the Metabolist movement, a group of younger architects, designers, and architecture critics. The members of the Metabolist group, formed for the 1960 World Design Conference held in Tokyo, worked in Tange's laboratory at the University of Tokyo's division for architectural engineering; they also decided to recruit a few others, like the rising young architect Kikutake Kiyonori (19282011). At this large international conference, co-organized by Tange Lab members, the Metabolists gained global fame through their "Metabolist manifesto'. ${ }^{13}$ The manifesto featured their utopian designs that were intended to promote an obligation of post-war Japanese architecture to serve social change. ${ }^{14}$ Rooted in modern architecture and combining it with ideas of biological ('metabolic') growth, the designs claimed universal applicability and

\footnotetext{
${ }^{12}$ Breakthrough Institute et al., An Ecomodernist Manifesto (San Francisco: Breakthrough Institute, 2015).

${ }^{13}$ Noboru Kawazoe et al., Metabolism. The Proposals for New Urbanism. Toshi e no teian (Tokyo: Bijutsu Shuppansha, 1960).

${ }^{14}$ Zhongjie Lin, Kenzo Tange and the Metabolist Movement. Urban Utopias of Modern Japan (London: Routledge, 2010), pp. 6-7.
} 
proposed new architectural tools for creating greater social equality, reducing potential for conflict, and flexibly adapting structures to meet individual needs and desires. Kikutake's proposals for Tokyo Bay from the late 1950s and 1960s, published in the manifesto, were thus utopian and technically unfeasible. However, later scholarly studies on Tange and his Metabolist mentees often mixed their utopian (unfeasible) and non-utopian (in toned-down form feasible) designs together. This strong concentration on Tange and the Metabolists also meant that the booming scholarship almost completely overlooked the fact that Tange's ideas were an integral part of a much broader, global discussion about cybernetics and marine urbanization-'metabolic' structures being cybernetic structures. ${ }^{15}$ Another consequence is that Fuller's ideas, their global legacy, and the similarities and differences between him and Tange were left out in previous studies. ${ }^{16}$ Moreover, Tange's and Fuller's intellectual legacy for environmental thought was not addressed at all.

\section{Post-war urban sprawl and Tokyo Bay in terrestrial and amphibious mindsets}

During the late 1950s and 1960s, Tokyo Bay became the target of discussions that focused on Tokyo's urban sprawl, population growth, and the related transportation network congestion. One answer was to stop or even reverse

\footnotetext{
${ }^{15}$ The main exception is Yuriko Furuhata, 'Architecture as Atmospheric Media: Tange Lab and Cybernetics', in Media Theory in Japan, (eds) Marc Steinberg and Alexander Zahlten (Durham: Duke University Press, 2017), pp. 52-79. I thank Alexander Zahlten for the reference. Other publications bring up Tange's focus on cybernetics in a couple of sentences: Lin, Kenzo Tange; Seng Kuan and Yukio Lippit (eds), Kenzō Tange. Architecture for the World (Zurich: Lars Müller Publishers, 2012). Most publications on Tange's and the Metabolists' Tokyo Bay designs overlook the global cybernetics boom: Hajime Yatsuka, Metaborizumu Nekusasu [Metabolism Nexus] (Tokyo: Ōmusha, 2011); Sōhei Imamura, 'Kikutake Kiyonori: “Kaijō Toshi”, in Metaborizumu no mirai toshiten. Metabolism: The City of the Future, (ed.) Mami Hirose (Tokyo: Shinkenchikusha, 2011), pp. 249-253; Rem Koolhaas and Hans Ulrich Obrist, Project Japan. Metabolism Talks... (Cologne: Taschen, 2011); Ken T. Oshima (ed.), Kiyonori Kikutake. Between Land and Sea (Zurich: Lars Müller Publishers, 2016); Hyunjung Cho, 'Kenzō Tange's A Plan for Tokyo, 1960: A Plan for Urban Mobility', Architectural Research Quarterly 22, no. 2 (2018), pp. 139-150; Raffaele Pernice, 'Images of the Future from the Past: The Metabolists and the Utopian Planning of the 1960s', Journal of Civil Engineering and Architecture 8, no. 6 (2014), pp. 761-771. This scholarship also (over)stated that Tange would have derived the 'metabolic' ideas that he used in the 'Plan' from the younger Metabolists and their proposals. As was recently argued, Metabolists like Kikutake Kiyonori also engaged in self-Orientalization, which promised global attention, by linking his ideas to premodern Japanese construction practices and religious thought: see Hyunjung Cho and Chunghoon Shin, 'Metabolism and Cold War Architecture', Journal of Architecture 19, no. 5 (2014), pp. 623-644, here: p. 624. Such self-Orientalization-and the research focus solely on Tange and the Metabolists-thus obscured this involvement in the global cybernetics boom.

${ }^{16}$ One exception is a comment that capsules, taking the form of geodesic spheres, which the Metabolists started using in the late 1960s and which became well-known symbols of Expo '70 in Osaka, go back to Fuller's geodesic domes: Lin, Kenzo Tange, pp. 220-221; Peter Šenk, Capsules. Typology of Other Architecture (London: Routledge, 2018), pp. 63, 85. Another exception is that at Expo '70, the Symbol Zone's space frame structure is reminiscent of Fuller's original plan for the American pavilion at Expo '67. Tange and co. were perhaps inspired by it: Martin Pawley, Buckminster Fuller (London: Trefoil Publications, 1990), pp. 164, 169.
} 
sprawl by redesigning the city and by using the Bay as an urbanized place of high population density. Tange, already a well-known architect, would become one of the major voices in the Tokyo Bay debate. After graduating from Tokyo Imperial University in 1936 and some time spent working in colonial Manchuria and other places, he returned to the university, first as a postgraduate student and, from 1948, as faculty member, opening Tange Lab. During the post-war period, he gained international fame as the designer of the Hiroshima Peace Memorial Museum (1952), followed in 1961 by the unrealized 'Plan'. As the most well-known Japanese architect of the twentieth century, Tange designed more than a hundred buildings, districts, and cities around the globe, among them the (former and present) Tokyo Metropolitan Government buildings (1957 and 1991), the Yoyogi National Gymnasium built for the 1964 Tokyo Olympics, St Mary's Cathedral Tokyo (1964), the Festival Plaza of the Osaka Expo (1970), several Middle Eastern royal and presidential palaces (1980s), and Nigeria's new capital in Abuja (1981). ${ }^{17}$

Urban sprawl and population growth, leading to the Tokyo Bay debate, were outcomes of Tokyo overcoming its war damage, Japan's reindustrialization, and the unfolding 'economic miracle'. Migration from rural areas to cities coincided with strong overall population growth. Japan's population increased by about 50 per cent between the early 1930s and the early 1960s to more than 90 million people. By 1960, Tokyo's population had grown continuously by about 300,000 people per annum, contributing to expectations that in 1970 the urban area would have further sprawled to accommodate more than 15 million people. As had been the case in many Western cities, tertiarization, the growing shift towards a consumer society, and the related massive increase in the number of delivery trucks and privately owned cars radically transformed mobility patterns and flooded transportation networks created during the pre-automobile age. ${ }^{18}$ Simultaneously, the building height limitation of 31 metres-largely due to earthquake concerns-put additional pressure on transportation networks and housing prices. Before the building height's modification in 1963, the drastic population rise thus caused a massive horizontal urban sprawl that increased the number of people commuting into the city's main economic districts. In the process, transportation networks experienced drastic congestion.

Colonizing the Bay was meant to create comparatively cheap space for urban design projects that were extremely difficult to realize on land because of strongly fragmented land ownership and a de facto lack of legal means for expropriation. Tange had been interested in Tokyo Bay quite early on. In 1957, he discussed the idea of a reclaimed island in the middle of it. ${ }^{19}$ However, the

\footnotetext{
${ }^{17}$ Kuan and Lippit, Kenzō Tange.

${ }^{18}$ Lin, Kenzo Tange, pp. 133-135. For Tange Lab's criticism, see Kenzō Tange et al., Tōkyō keikaku 1960. Sone kōzō kaikaku no teian [A Plan for Tokyo, 1960. Proposal for a Structural Reorganization] (Tokyo[?]: Tange Kenzō Kenkyūshitsu, 1961), pp. 26-29. The Japanese text of Tange Lab's 'Plan' is more detailed and more precise than the English text.

${ }^{19}$ Seng Kuan, 'Land as an Architectural Idea in Modern Japan', in Architectualized Asia: Mapping a Continent through History, (eds) Vimalin Rujivacharakul et al. (Honolulu: University of Hawai'i Press, 2014), pp. 189-203, here: pp. 197-198.
} 
Tokyo Bay debate was sparked in April 1958 by Kanō Hisaakira, president of the public Japan Housing Corporation (Nihon Jūtaku Kōdan). Kanō first released a proposal for a huge land reclamation project that encouraged others to think about alternative, amphibious approaches. In Kanō's proposal, levelling the Nokogiriyama mountain range of the Bōsō Peninsula (framing the east of Tokyo Bay) with nuclear blasts would provide sufficient material to fill the Bay's northern part between Tokyo and Chiba. This debatable plan attracted the attention of architects Ōtaka Masato and Kikutake Kiyonori, two future members of the Metabolist movement, and their mentor Tange. ${ }^{20}$

Tange Lab's 'Plan', and before it Ōtaka's and Kikutake's ideas, were inspired by the problems related to terrestrialization through land reclamation. The lack of stability of buildings that were erected on a huge reclaimed space was a concern in Kanō's proposal. As a consequence, he foresaw buildings being based on piers standing on the solid rock of the Bay's floor, meaning both reclamation and pier construction. In 1958 Ōtaka was just finishing a highrise apartment complex in Tokyo's Harumi district on reclaimed land and was aware of its problems. In a counter-proposal published in February 1959, he criticized Kanō's approach as silly and expensive, arguing instead for an amphibious approach through elevation on piers without terrestrialization through reclamation. ${ }^{21}$ This is important, since both Tange Lab's and Fuller's designs served to circumvent such large-scale land reclamation and its ecological footprint of the complete destruction of marine ecosystems. Doing so, however, became the preferred solution for Japanese civil servants. Today about 250 kilometres ${ }^{2}$ of Tokyo Bay, mostly located in Tokyo's harbour, are reclaimed. To be sure, land reclamation had a long history in Tokyo Bay. ${ }^{22}$ However, the aforementioned amphibious or floating adaptation approaches of ebune and others also had a long-and partially urban-history in Japan, Asia, and globally. Japanese civil servants opting for land reclamation, instead of elevation or flotation, as their preferred solution therefore represented the terrestrial mindset that was dominant in Japan.

One of the main hindrances of marine urbanization was, I argue, that the twentieth century experienced a worldwide land reclamation, hydroelectric dam construction, and coastal defence upgrading spree, globally causing or intensifying a terrestrial mindset that turned water into an object of fear and danger. Amphibious or floating architecture did not suppress or bar water flows. Instead, the aim was to reduce vulnerability and prevent significant damage by adapting to regular floods and changes in water level. of course hydroelectric dam construction created water reservoirs (and the enforced relocation of local people), but my point is that a far greater area experienced a land reclamation process through the control and removal of

\footnotetext{
${ }^{20}$ Ibid., pp. 196-197; Lin, Kenzo Tange, pp. 140-141.

${ }^{21}$ Masato Ōtaka, 'Kōsō apāto o haichi shita atarashii jūtakuchi no teian to Tōkyō wanjō toshi no teian [Proposals for a New Residential District Based on High-rise Apartments and for a City on Tokyo Bay]', Kenchiku bunka 148 (February 1959), pp. 39-42.

${ }^{22}$ Takeshi Endō, 'Tōkyōto rinkaiiki ni okeru umetatechi zōsei no rekishi [History of Land Reclamation along Tokyo's Waterfront]', Chigaku zasshi 113, no. 6 (2004), pp. 785-801.
} 
waters that had perennially flooded amphibious environments. This terrestrialization process changed amphibious spaces like floodplains into places where terrestrial settlement and industrialization strategies could be applied. The related terrestrial mindset that shaped regional development thus devalued amphibious or floating adaptation approaches, such as (wooden) stilted or raft houses, as premodern, low-tech, and primitive. From the late nineteenth century, hydroelectric dam experts began to transform Japan and also its colonial empire in Korea and Manchuria, where terrestrialization and the related promise of regional industrial development became a tool to legitimize colonial rule. After the war, leading Japanese dam engineers continued their careers by utilizing the demands for reparations. These were paid, in part, through construction projects, such as Burma's first dam, built between 1954 and 1960. In the late 1960s, such Japanese experts also convinced the Indonesian government to construct the Asahan River Dam in northern Sumatra. Similarly, China, India, south Afghanistan, the Mekong and Chao Phraya river deltas, and other parts of Asia experienced a hydroelectric dambuilding spree. ${ }^{23}$ While in the first half of the nineteenth century hardly any such dams existed in the world, now there are more than 89,700 , the vast majority of them located in Asia, or rather China. ${ }^{24}$ I see such projects as strong contributions to and expressions of the terrestrial mindset in regional development. In that sense, Tange Lab's 'Plan' will be interpreted as a countermodel to hydroelectric dams and land reclamation; it was therefore also a regional development project-but one that rejected the terrestrial mindset in favour of an amphibious design.

\section{Designing a cybernetic megastructure: communication networks above and beyond Tokyo Bay}

The protagonists of this article saw Tokyo Bay not only as an aquatic body but, primarily, as a future nodal point in global communication networks, which they believed would operate and guide urban expansion on land and at sea. Tange Lab's 'Plan', in terms of its intellectual history, therefore not only

\footnotetext{
${ }^{23}$ On Japanese dam experts like Kubota Yutaka, see Aaron S. Moore, Constructing East Asia. Technology, Ideology, and Empire in Japan's Wartime Era, 1931-1945 (Stanford: Stanford University Press, 2013), pp. 150-187; Aaron S. Moore, 'Japanese Development Consultancies and Postcolonial Power in Southeast Asia: The Case of Burma's Balu Chaung Hydropower Project', East Asian Science, Technology and Society 8 (2014), pp. 297-322; Aaron S. Moore, "'The Yalu River Era of Developing Asia": Japanese Expertise, Colonial Power, and the Construction of the Sup'ung Dam', Journal of Asian Studies 72, no. 1 (2013), pp. 115-139, here: p. 133. See also John R. McNeill and Peter Engelke, The Great Acceleration. An Environmental History of the Anthropocene since 1945 (Cambridge, MA: Harvard University Press, 2014), pp. 32-36; David Ekbladh, The Great American Mission. Modernization and the Construction of an American World Order (Princeton: Princeton University Press, 2010), pp. 163-167; Nick Cullather, 'Damming Afghanistan: Modernization in a Buffer State', Journal of American History 89, no. 2 (2002), pp. 512-537. See also the literature in footnote 7.

${ }^{24}$ Thiago B. A. Couto and Julian D. Olden, 'Global Proliferation of Small Hydropower PlantsScience and Policy', Frontiers in Ecology and the Environment 16, no. 2 (2018), pp. 91-100; Vaclav Smil, Energy Transitions: History, Requirements, Prospects (Santa Barbara: Praeger, 2010), p. 45.
} 
goes back to other Tokyo Bay proposals and Tange's wartime projects. It also incorporated elements of Tange's cybernetics research at MIT, where he served as visiting professor in the autumn of 1959. In that sense, Tange Lab's design moved central ideas of modernist architecture into the cybernetics-based information age of global networks.

Tange Lab's 'Plan' focused on an elevated megastructure that would maximize access to communication networks, which for Tange was the reason why people flocked to cities. During a course that he taught at MIT in autumn 1959 Tange had emphasized the 'enormous amounts of energy' that nuclear technology would provide. ${ }^{25}$ This promise of cheap energy, which could power the many electronic and, to a lesser degree, transportation-based communication networks, needs to be understood as a reason why Tange thought about designing a cybernetic megastructure at all. Using a linear city concept running along a highway, the megastructure would grow and eventually connect Tokyo to Chiba Prefecture across the Bay, thereby preventing radial urban sprawl (see Figure 1). Suspended from piers, the multi-lane and multi-level highway network was elevated 40-50 metres above the ground, small reclaimed areas, and the Bay's seafloor, constituting the Civic Axis. The Civic Axis was divided into one minor and 11 major cycles, many of them including three smaller highway loops (see Figure 2). Altogether, eight of the major, three kilometre-long cycles were suspended above the Bay, while on land the minor and three major cycles moved into downtown Tokyo and Kisarazu in Chiba Prefecture. Perpendicular and parallel to the Civic Axis's offshore parts, several cycles featured A-frame buildings (resembling an 'A' from the side) elevated above the Bay's surface and serving as residential properties for three million people (see Figure 3). Individual dwelling units were supposed to be constructed on their surfaces (although Tange Lab did not go into the details of how this was to be realized). Many cycles also encircled huge cores, which combined the idea of pilotis-meaning piers lifting a building above ground or water-with that of communication and transportation infrastructures. Like circulation cores of buildings, the cores harboured passenger and freight elevators, water ducts, and electric wiring, emphasizing that the overall structural purpose was to create networks that channelled the uninterrupted flow of information, people, and energy. Suspended between the huge cores were bridge-like structures mostly providing office space for up to 2.5 million people, serving the nation's most central economic, governmental, administrative, and consumption functions (see Figure 3$)^{26}$

Tange's cybernetic ideas for megastructure construction seem to have begun with the analogy of leaf-bearing trees and the authority of 'trial and error'proven evolution of biological communication systems. Such a biological communication system allows a tree to sustain itself by operating the seasonal growing and discarding of its leaves. In September 1959, Tange participated

25 ‘4.151 Architectural Design. First Term 1959-1960’, p. 1, in C002: New Community on the Sea, 1959, The Kenzo Tange Archive, Gift of Mrs. Takako Tange, 2011, Frances Loeb Library, Harvard University Graduate School of Design, Cambridge, MA, United States (hereafter cited as TKTA).

${ }^{26}$ Tange et al., Tōkyō keikaku. 


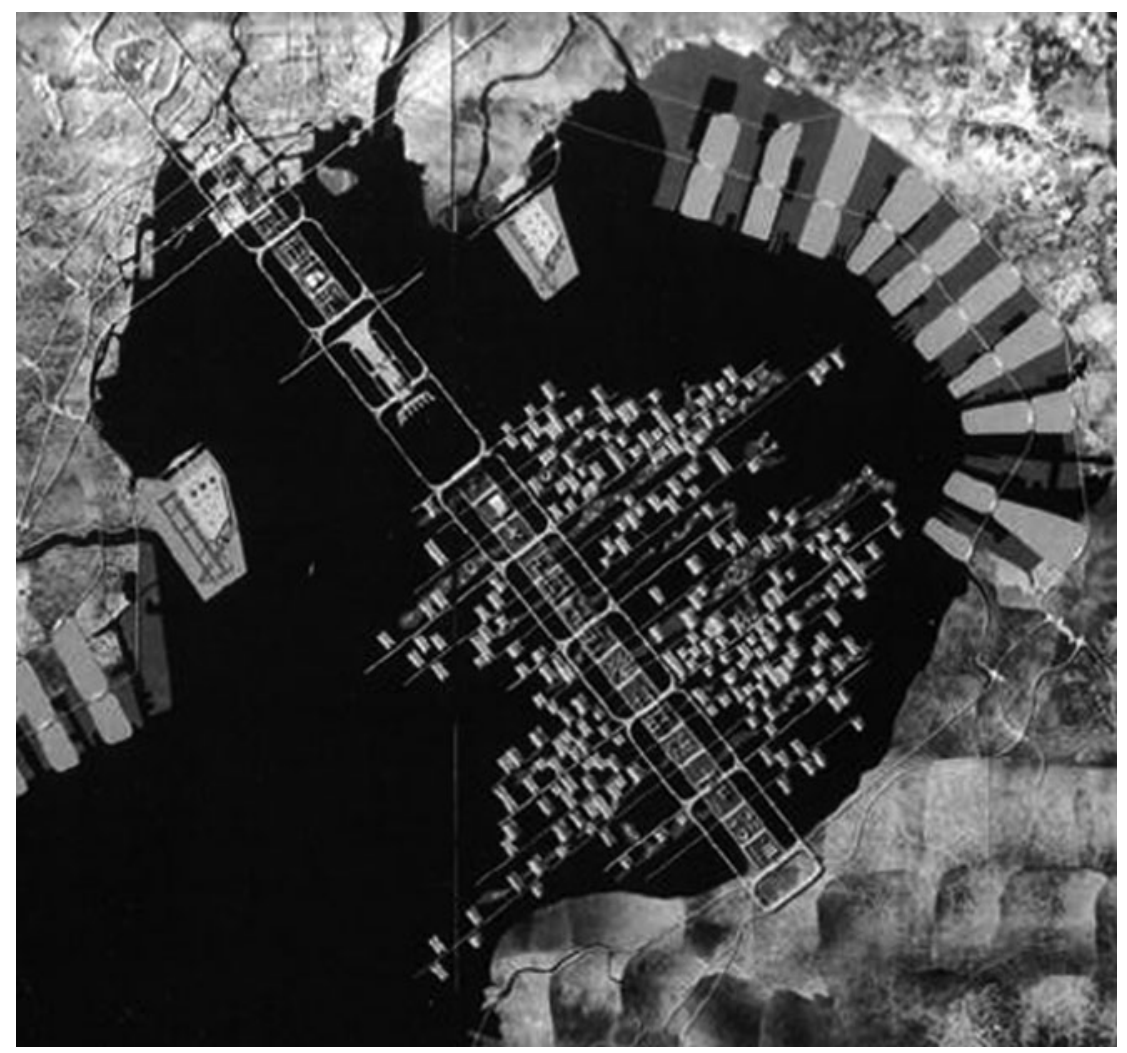

Figure I. Bird's-eye view of Tange Lab's 'Plan for Tokyo 1960': the cycles of the Civic Axis lineally cross the Bay from Tokyo to Chiba Prefecture, with residential areas perpendicular and parallel to them. Source: Tange et al., Tōkyō keikaku 1960, p. 30. Photo taken by @ Akio Kawasumi, courtesy of Tange Associates (Tokyo) and TKTA.

in the last meeting of CIAM (International Congresses of Modern Architecture) in Otterlo, Netherlands, an event attended by many of the world's most prominent architects. In addition to his own projects, he presented some of Kikutake's utopian designs for Tokyo Bay. He also explained Kikutake's view that 'Tokyo is expanding but there is no more land so we shall have to expand into the sea. ${ }^{27}$ What is even more important is that he brought up Kikutake's structural understanding of a megastructure as a tree. Tange explained that in Kikutake's understanding, a long-lived or permanent structural element represented the tree's trunk, while short-lived elements built on it, such as individual dwellings, represented leaves that can be discarded and renewed, whenever necessary. ${ }^{28}$ This analogy goes back to Kikutake's 'Tower-Shape Community',

27 Oscar Newman, New Frontier in Architecture: CIAM 59 in Otterlo (New York: Universe Books Inc., 1961), p. 184.

${ }^{28}$ Ibid. 


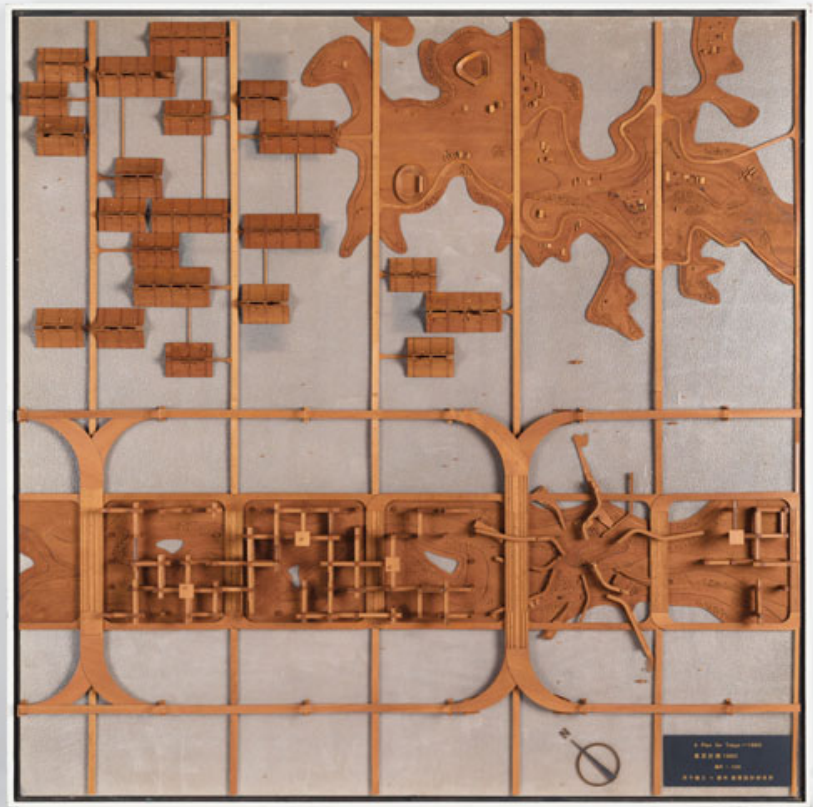

Figure 2. Bird's-eye view of one loop (being part of a bigger cycle) and a residential area located perpendicular and parallel to it. Source: Kenzō Tange, Tokyo Bay Model, KTA_D00I-00I_005 (seq. 5), TKTA, https://iiif.lib.harvard.edu/manifests/view/drs:4536775I25i, [accessed I6 June 202I]. Courtesy of TKTA.

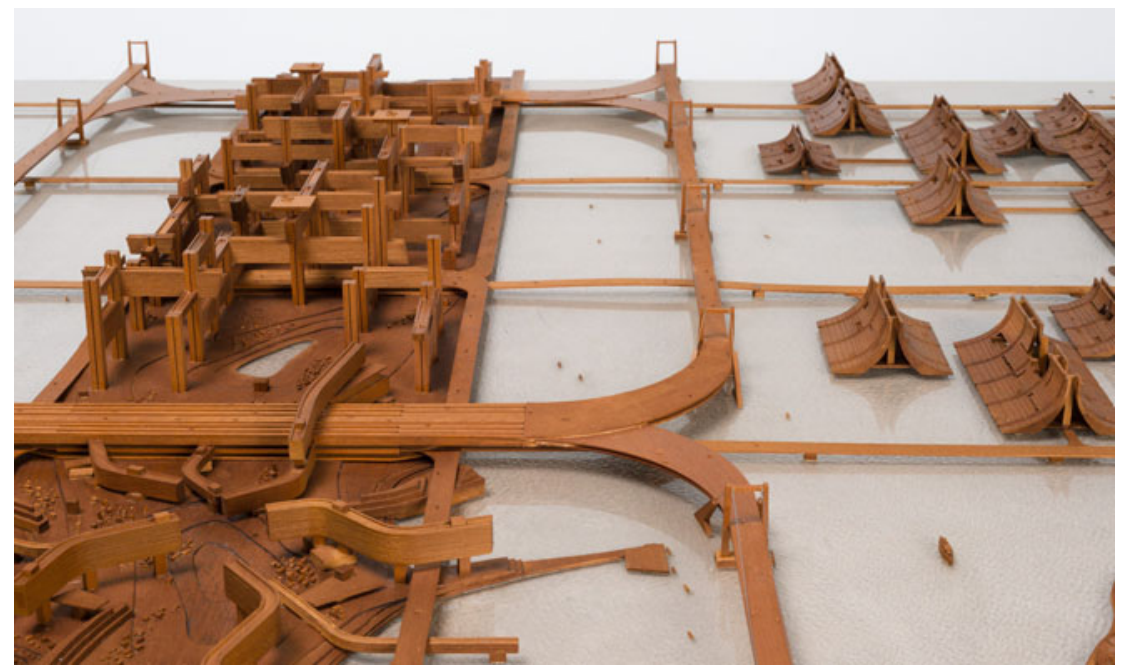

Figure 3. View of one loop, with office buildings suspended between huge cores located inside it, and a residential area with elevated A-frame structures perpendicular and parallel to it. Source: Kenzō Tange, Tokyo Bay Model, KTA_D00I-002_023 (seq. 23), TKTA, https://iiif.lib.harvard.edu/manifests/ view/drs:45367752I23i, [accessed I6 June 202I]. Courtesy of TKTA. 
which had been published in early 1959. In this utopian, socially critical text, Kikutake developed the idea of short-lived dwelling units attached to and removed from a long-lived structure in the form of a tower:

Like trees that in accordance with the cycle of the four seasons produce new buds and whose leaves eventually turn red, then die and fall down, a dwelling unit will be connected to a human family and their life. The dwelling unit will be made of steel, because steel's lifespan, that is 50 years, is most suitable to serve a family's life. The steel unit which has fulfilled its duty will be [taken down], scrapped, and remanufactured into a new dwelling unit to serve a new family's life. ${ }^{29}$

Kikutake had also used this idea to build, on a much smaller and technically feasible scale, his own house in 1958. Here, 'movenette' rooms serving different purposes over the course of a family's life could be attached and removed. ${ }^{30}$ In the case of the 'Tower-Shape Community' design, still simple modularization technology thus served to enable flexible growth through additions when demand arose. Such additions then increased population density until the maximum number of dwelling units was reached. A simple form of mobility of the modules, in the sense of their renewability without having to demolish the whole megastructure and to build a new one, further served to reduce urbanization's ecological footprint. Tange and his colleagues then advanced these very basic proto-ecomodernist ideas by applying them to amphibious and floating architecture.

In terms of Tange's role in the global cybernetics boom, he without question drew inspiration from his Metabolist mentees, including Kikutake, but also from other publications, among them Norbert Wiener's cybernetics studies on communication networks and democratization, and his own travels. ${ }^{31}$ After all, Tange's visiting professorship at MIT, one of the centres of the cybernetics boom, allowed him to make his own urban design-related contributions that ultimately merged networks-based growth, mobility, autonomy, and adaptation to marine surfaces. Driven by Wiener, MIT was one of the central institutions in cybernetics research. ${ }^{32}$ After attending CIAM, Tange commenced his visiting professorship during the autumn term of 1959, teaching a course in architectural design titled 'New Community on the Sea. 25,000 Habitants on the Boston Bay'. Tange afterwards presented a design based on that course

${ }^{29}$ Kiyonori Kikutake, 'Tōjō toshi [Tower-Shape Community]', Kokusai kenchiku 26, no. 1 (1959), pp. 12-19, here: p. 18.

${ }^{30}$ Newman, New Frontier, p. 184.

${ }^{31}$ Regarding Tange's particular interpretation of Wiener's writings on the Second Industrial Revolution, on communication systems and democracy, and on ant communities and fascist ideas of fixed social orders, see Kenzō Tange, Nihon rettō no shōraizō. 21-seiki e no kensetsu [A Vision of the Future of the Japanese Archipelago. Constructing for the 21st Century] (Tokyo: Kōdansha, 1966), pp. 32-35, 42. See also Norbert Wiener, The Human Use of Human Beings. Cybernetics and Society (London: Free Association Books, 1989; first and second editions 1950 and 1954), pp. 27, 39, 50-59, 136-162.

${ }^{32}$ Kline, The Cybernetics Moment, pp. 68-101, especially p. 101. 
at the 1960 World Design Conference in Tokyo, the event where the Metabolist movement was founded. Its text was based on the work of one student group and already featured several cybernetic ideas that would soon be of central importance for the 'Plan' and then shape ecomodernist marine urbanization. ${ }^{33}$

\section{Tange Lab's designs and proto-ecomodernist thought}

Coming back to the cybernetic analogy of the biological growth of a tree, one of Tange's central ideas was to enable the megastructure to grow, which went beyond the capability to add short-lived elements like houses. The proposal for Boston Bay, based on the students' project, which had taken up Kikutake's tree and leaves analogy, then began to search for a new design: ${ }^{34}$ 'Can the major structure not have the same possibility for growth as a tree trunk?' ${ }^{35}$ Tange Lab's 'Plan' became the answer: the 'Plan' served to replicate the growth of a fully operational biological system, not just its short-lived organs, like leaves. Growth of the whole Civic Axis, which would remain fully operational during expansion work, would take place in four or more stages. ${ }^{36}$ Such growth would be implemented at points in time when economic or demographic factors encouraged it. Tange Lab just switched the example of a growing tree trunk with the growth of a vertebral column in an embryo: 'The system [Civic Axis] is composed of cycles, somewhat like the vertebrae in the spine. At each stage of development, the transportation system is complete. But there is no end point, at any point it is possible to develop and extend it through another unit. ${ }^{37}$ Tange Lab's example of the vertebrae also further stressed a particular, linear structure, to be replicated by a linear city. After all, the vertebral column provides the structure for the spinal cord, meaning a vertebrate's central, linear communication 'highway' (see also Figure 4):

Protozoans like amoebae and starfishes have radial centripetal forms, but vertebrates have linear bone structures with parallel radiations. When the living functions of organisms differentiate and perform the composite function of life, the centripetal pattern evolves into a system of parallel lines grouped around an axis formed of a spine and arteries. ${ }^{38}$

Comparing the growth patterns of communication systems of 'simple' life forms to more 'complex' ones, thus invoking what they saw as the authority of hundreds of million years of evolution, Tange Lab further emphasized the message that urban forms had to evolve like biological life operated by these systems: passing through different stages over the course of human history, 'simple' settlements with an urban core had to evolve to complex and

\footnotetext{
${ }^{33}$ Kenzo Tange, 'A Building and a Project: On the Kurashiki City Hall and a Project at MIT', Ekistics 11, no. 68 (1961), pp. 469-472, 474-476.

${ }^{34}$ See the student project abstracts in C002: New Community on the Sea, 1959, TKTA.

${ }^{35}$ Tange, 'A Building', p. 472.

${ }^{36}$ Tange et al., Tōkyō keikaku, pp. 36-37.

${ }^{37}$ Ibid., p. 29 (quotation).

${ }^{38}$ Ibid.
} 
spine in primitive stage

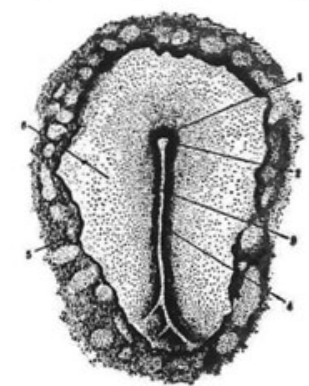

']

\begin{abstract}
fourth somitic stage
\end{abstract}

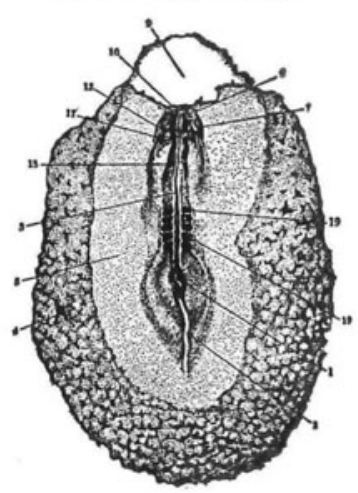

sixteenth somitic stage

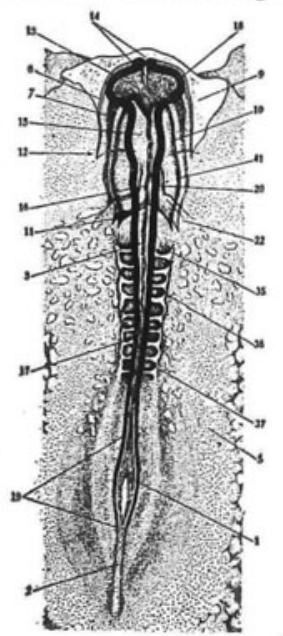

nineteenth somitic stage

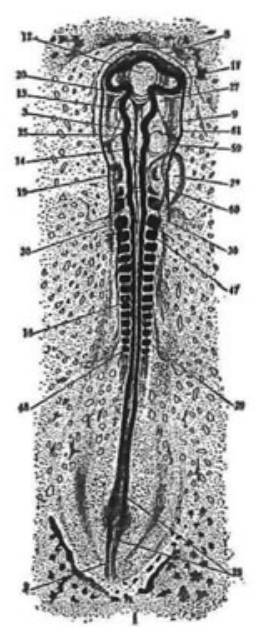

Figure 4. One of Tange Lab's biological analogies, with the linear growth of an animal spine being the efficiency model for the growth of a linear city, to be realized in the 'Plan for Tokyo 1960'. Source: Tange et al., A Plan for Tokyo, 1960, p. 13. Courtesy of TKTA and the University of Tokyo. 
gigantic linear urban zones, which, due to communication network connectivity, would include both marine and terrestrial places.

Tange Lab's amphibious transformation project advanced the protoecomodernist idea of replicating and substituting biological communication systems with technology far beyond what the 'Tower-Shape Community' and the Boston Bay designs had done. Flexible expansion of the linear communication network guided high population-density urban growth instead of uncontrolled horizontal urban sprawl. Such high population density served to reduce the environmental degradation that is otherwise attendant to urban sprawl, particularly if it happens on the ground level. Or, as Tange remembered his linear city-related intention of limiting the ecological footprint both on land and at sea in 1966: 'If compact urban environments are constructed, then nature can be preserved, the countryside can remain a beautiful countryside, and the sea can remain a beautiful sea. ${ }^{39}$ Growth also was made flexible, taking place only in case of demand, based on a simple idea of autonomy. At any stage of growth, the Civic Axis would be functional.

\section{Tange, Fuller, and cybernetics at the Delos symposiums on human settlements}

In the years following the publication of the 'Plan', Tange expanded his focus to cybernetic regional planning, which would bring his ideas into contact with Fuller's. Tange began to think about a huge communication, transportation, and energy network operating and guiding the growth of a linear city, or rather a linear megalopolis, in eastern coastal Honshū, Japan's most densely settled urban corridor. ${ }^{40}$ Transferring the linear city idea for Tokyo Bay to a huge terrestrial space utilized ongoing governmental projects. The construction of the Shinkansen high-speed railway line along the historical Tōkaidō road (Eastern sea road) began in 1959 and connected cities from Tokyo to Osaka. ${ }^{41}$ For centuries, as a consequence of Japan's geography, the Tōkaidō road and its maritime equivalent along the Pacific coast had been central trade and communication networks. ${ }^{42}$ In Tange's case, mobility and a kind of linear city in that region had been on his mind for decades. In 1942, a young Tange had won the competition for a Greater East Asia Co-Prosperity Sphere National Memorial, a reminder of the design legacy of Japanese expansionism. Tange had conceptualized the unrealized memorial at the foot of Mount Fuji not as a secluded site but as directly connected to a linear 'Greater East Asia Highway'. This highway was supposed to run from the imperial palace in Tokyo through Honshū's major cities to Kyoto, directing

\footnotetext{
${ }^{39}$ Tange, Nihon, p. 85.

${ }^{40}$ See, in particular, Tange, Nihon; Kenzō Tange, 'Daitoshi kaihatsu no bijon [Vision of the Development of a Metropolis]', in Nihon no chiiki kaihatsu [Japan's Regional Development], (ed.) Nihon Chiiki Kaihatsu Sentā (Tokyo: Daiyamondo, 1965), pp. 221-231.

${ }^{41}$ Jessamyn R. Abel, 'The Power of a Line. How the Bullet Train Transformed Urban Space', Positions 27, no. 3 (2019), pp. 531-555.

${ }^{42}$ Jeffrey E. Hanes, 'From Megalopolis to Megaroporisu', Journal of Urban History 19, no. 2 (1993), pp. 56-94, here pp. 58-65.
} 
the development of Japan's future urban expansion towards an enormous linear city. ${ }^{43}$ The new Shinkansen network, together with the implementation of plans for a national highway network, therefore served as the backbone of Tange's cybernetic regional planning idea.

Earlier, Kikutake had integrated a floating structure and a stronger offshore focus into such linear city ideas. Before the publication of Tange Lab's 'Plan' in 1960, Kikutake had created a utopian mix of a potential linear city and an offshore oil platform-inspired 'floating city'. Reminiscent of the Tōkaidō road and Tange's wartime highway idea, Kikutake envisioned a highway running on land and partially offshore along Honshū's eastern coastline from south Hokkaidō to north Kyūshū, connecting Japan's major industrial areas. While the utopian plan lacked technical details and was not meant to be implemented, Kikutake had placed a 'floating city', Unabara (Ocean City), in Sagami Bay, located to the southwest of Tokyo Bay. ${ }^{44}$ There, it would help to create what Kikutake could have called an amphibious linear industrial belt. Given his mentor-mentee relationship with Tange, Kikutake's utopian combination of a linear amphibious highway for mobility purposes and a mobile, floating megastructure must have had an inspirational impact on Tange during the following years-and, through him, also on Fuller.

Fuller, arguably, was the most controversial American designer of the twentieth century. Dismissed twice from Harvard University as an undergraduate student during the 1910s, he served as a naval officer during the First World War, followed by several years of work in the construction business. Debatable behaviour and sales practices resulted in him changing his focus to designing, journalism, and book-writing. During the late 1920s and early 1930s, his ideas for new forms of housing and cars, shaped by radically applying the most recent scientific findings to his designs, made him well known but did not result in commercial successes. It was only during the Second World War that the American military became a customer for his ecologically largely autonomous housing designs, which could be relocated and made usable quickly. After the War, Fuller gained international fame though his promotion of the geodesic domes that are still strongly associated with him and which turned into a financial success. Fuller also became a major advocate of cybernetics in his urban design plans which, due to their radical departure from usual schemes, continued to find global interest but not commercial appeal. As a consequence, he quite successfully created a personal myth of enduring great deprivations in his quest to improve living conditions all over the globe. ${ }^{45}$

In 1966, Fuller developed his 'Tetrahedronal City' design for Tokyo Bay. In late spring of that year, during the heyday of the Japanese economic miracle, he had been contacted by Shōriki Matsutarō's staff to probe the technical feasibility and economic costs of a building: the 'Nippon TV Tower', higher than

${ }^{43}$ On Tange's Memorial project, see Lin, Kenzo Tange, pp. 48-51.

${ }^{44}$ Kawazoe et al., Metabolism, p. 27.

45 On Fuller and his personal myth, see Loretta Lorance, Becoming Bucky Fuller (Cambridge, MA: MIT Press, 2009). On the long-term importance of his design methodology, see Jonathon Keats, You Belong to the Universe. Buckminster Fuller and the Future (Oxford: Oxford University Press, 2016). 
Mount Fuji (3,776 metres). Shōriki had accumulated substantial wealth as the owner of the Yomiuri newspaper company, 'Yomiuriland' amusement park (opened in 1964), a professional baseball team, and Nippon TV, Japan's first commercial television broadcaster. In 1963, Tokyo's building height restriction of 31 metres had been modified, leading to the construction of substantially taller buildings in the following years. ${ }^{46}$ At about that time, Walt Disney also developed the idea of building a high-tech prototype urban community in the United States, which may have had an inspirational impact on Shōriki as a fellow amusement park owner. ${ }^{47}$ Fuller and his team started working on the design for the tower in summer 1966 and soon afterwards received a modified request. What Shōriki now wanted to investigate was a possible solution for Tokyo's rapidly rising population by turning the 'Nippon TV Tower' into a settlement for one million people, in addition to its function as television broadcasting tower. On 2 August 1966, in response to the request for such a gigantic vertical settlement, Fuller began to think about an unsolicited alternative design: a floating tetrahedral settlement to be located in Tokyo Bay (see Figure 5). ${ }^{48}$ Without question, this unsolicited design was a direct outcome of his meeting with Tange in July.

In July 1966, Fuller and Tange met at the Fourth Delos Symposium, a famous annual event that Fuller was invited to attend every year. In 1966 Greek urban planner Constantinos A. Doxiadis, founder of the event, also invited Tange because of the symposium's growing interest in the role of cybernetics in urban planning on a global scale. In a sense, the Delos meetings succeeded the CIAM conferences. As Mark Wigley described, during the early Delos meetings the CIAM ideas of functional urban units being connected by physical transportation networks, which had once inspired a young Tange, shifted towards a 'network fever' and the idea of inhabiting electronic communication networks. From the first meeting in 1963, Fuller, who for decades had been designing autonomous buildings that were communication network-connected through radio, and media theorist Marshal McLuhan, who had just developed the idea of the 'global village', had argued along these lines. At the end of the fourth meeting, all participants accepted the point that communication networks had produced a single, planetary society and that urbanization could

\footnotetext{
${ }^{46}$ Shoji Sadao, 'Buckminster Fuller's Floating City', The Futurist 3, no. 1 (1969), pp. 14-16, here: p. 14; Shoji Sadao, Buckminster Fuller and Isamu Noguchi. Best of Friends (Milan: 5 Continents Editions, 2011), pp. 187, 244; Hiroshi Watanabe, The Architecture of Tokyo (Stuttgart: Edition Axel Menges, 2001), p. 119. Earlier, in 1961, Shōriki had been in contact with Fuller's company regarding the (eventually abandoned) purchase of geodesic dome licences: Agreement Fuller and Shoriki, 30 May 1961, in M1090: R. Buckminster Fuller Papers, Series 21, Box 8, Folder 8, Special Collections, Stanford University Libraries, Palo Alto, United States (hereafter cited as SUL).

${ }^{47}$ On Disney's plan for an 'Experimental Prototype Community of Tomorrow' (EPCOT), which after his death in December 1966 was strongly modified, see Angela Ndalianis, 'Disney's Utopian Techno-Futures. Tomorrow's World That We Shall Build Today', in Tourist Utopias. Offshore Islands, Enclave Spaces, and Mobile Imaginaries, (ed.) Tim Simpson (Amsterdam: Amsterdam University Press, 2017), pp. 143-165.

${ }^{48}$ Sadao, Buckminster Fuller, pp. 188, 244. Sadao's claim in the text that Shōriki asked them to focus on the 'Tetrahedronal City' design is contradicted by Shibata Hidetoshi's letter mentioned below, in footnote 53 .
} 


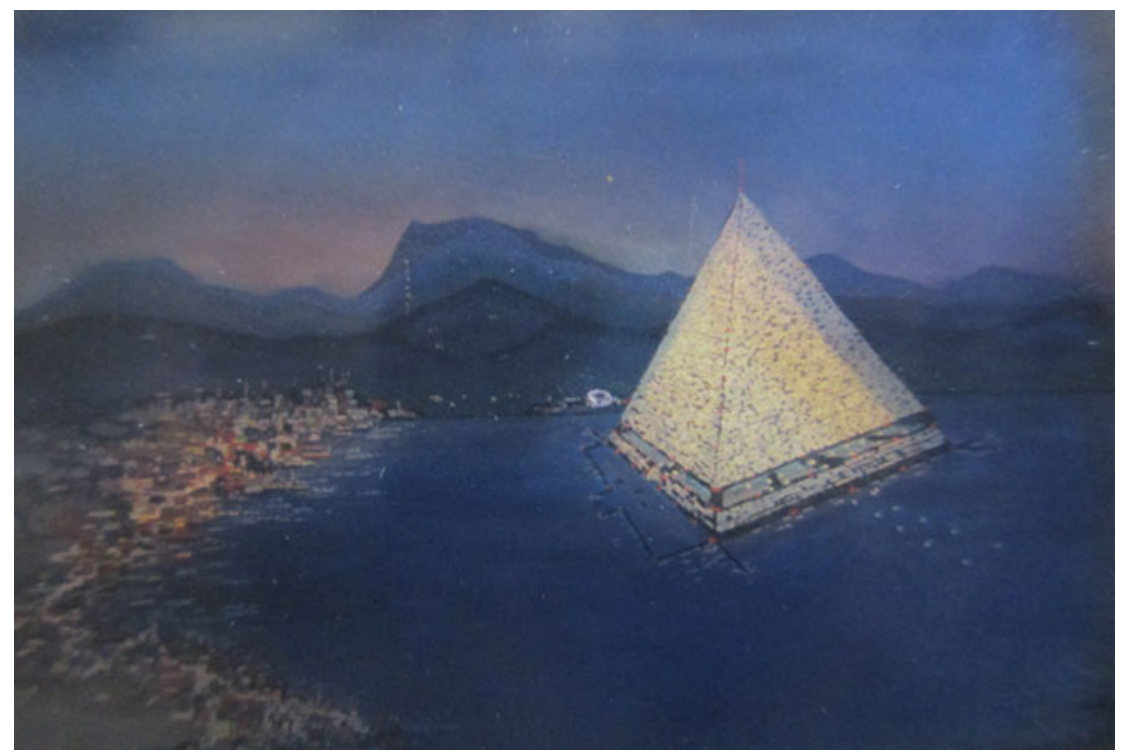

Figure 5. Image of the 'Tetrahedronal City' floating in Tokyo Bay. Source: Image, in MI090: R. Buckminster Fuller Papers, Series I5, Box 7, SUL. Courtesy of The Estate of R. Buckminster Fuller.

no longer be discussed without considering artificial communication systems. ${ }^{49}$

Tange's cybernetic focus on transportation and communication networks as a tool to guide the growth of a Japanese megalopolis directly connects to Fuller's work. The same is true for his idea that a democratic society could be created by increasing the mobility of information and people through network efficiency. At the symposium, Tange presented a summary of his cybernetic ideas of strongly network-connected megalopolises, which therefore analogically became, as he said, the 'brains for the body of modern society'. The discussion of his linear megalopolis idea for Honshü's eastern coastline must have caused Fuller to understand Tokyo Bay as the central hub of a cybernetics-based urbanization process. In that sense, Fuller took up some of Tange's and also Kikutake's cybernetics ideas on how to implement urban growth, mobility, autonomy, and adaptation to marine surfaces. After all, when evaluating the exchange of ideas that must have taken place at the symposium, it is noteworthy that Fuller's design for Tokyo Bay is in several ways strongly reminiscent of Tange's designs. Both Fuller and Tange shared the

\footnotetext{
${ }^{49}$ Mark Wigley, Buckminster Fuller Inc. Architecture in the Age of Radio (Zurich: Lars Müller Publishers, 2015), pp. 305, 313.

${ }^{50}$ Tange, Nihon, pp. 32-35, 42. The parts on cybernetics in his book, published in May 1966, are almost identical to the excerpts of his presentations at the Delos Symposium: Kenzo Tange, 'Need for New Approach to Transportation Networks', Ekistics 22, no. 131 (1966), pp. 258-259 (quotation: p. 259); Kenzo Tange, 'Need for More Balance in the Flow of Communication', Ekistics 22, no. 131 (1966), pp. 274-275.
} 
central idea of urbanizing Tokyo Bay through network expansions that eliminated the remoteness of marine surfaces. They also adapted the designs to the Bay, instead of land reclamation that was favoured by a terrestrial mindset. In that sense, Fuller's 'floating city' plan is also reminiscent of Kikutake's Unabara 'floating city' proposal, serving as an industrial hub in the envisioned emerging amphibious industrial belt, which would necessitate network-connectedness. Moreover, the actual shape of Fuller's design reproduced some of Tange's ideas. Fuller proposed a tetrahedral shape with residential units set up in rows on its terraced faces, while the communication, transportation, and energy networks were located inside. It was the same way that Tange and colleagues had structured the A-frames-and the dwellings situated on them-in the Boston Bay and Tokyo Bay designs.

Fuller's proposal may have concluded a full cycle. Mark Wigley recently argued that Fuller's lectures at the Japan Architects Association (Nihon Kenchikuka Kyōkai) in Tokyo in March 1958 and March 1959 are likely to have introduced the Metabolists to his own cybernetic ideas. Arguably, this could have contributed to Kikutake's aforementioned tree idea, which then influenced Tange. ${ }^{51}$ The Metabolists never mentioned Fuller's work, even though it was known in Japan, as a direct inspirational influence, for example, on the capsule designs they became famous for, although traces of such influence can be reconstructed. ${ }^{52}$ But then again, Fuller did not mention Tange or Kikutake in connection with his Tokyo Bay proposal either. Altogether, I see the publications, presentations, and international trips of Fuller, Tange, Kikutake, and many others as elements in the global cybernetics boom, where ideas were rather liberally appropriated, modified, and applied to new contexts.

\section{Tokyo Bay and proto-ecomodernism in the space age}

Between autumn 1966 and May 1967, Fuller unsuccessfully pushed Shōriki and his staff to consider his Tokyo Bay idea. Arguably an outcome of Shōriki's terrestrial mindset, one of his staff members emphasized that the one million people settlement should be part of the tower design, but Fuller did not understand the seemingly soft Japanese 'no' to his unsolicited alternative. That was, until his business partner, Japanese American Shoji Sadao, flew to Japan and talked with Shōriki's staff. ${ }^{53}$ While Fuller spoke to American media about the design's benefits for Tokyo's urban and environmental situation, the idea remained almost unknown in Japan. Shōriki had asked for confidentiality to prevent a potential loss of face. This was understandable since the cost calculation for the tower that Fuller and Sadao later provided was economically unfeasible. Considering Shōriki's media influence, it is not very surprising that the first brief article in Japanese about the Tokyo Bay design only

\footnotetext{
${ }^{51}$ Wigley, Buckminster Fuller, p. 317. Kikutake's 'Tower-Shape Community' is reminiscent of Fuller's 4D Lightful Tower and 4D Dymaxion House; see Šenk, Capsules, p. 68.

${ }^{52}$ Lin, Kenzo Tange, pp. 220-221; Šenk, Capsules, pp. 63, 85; Pawley, Buckminster Fuller, pp. 164, 169.

${ }^{53}$ Hidetoshi Shibata, Dear Dr. Fuller, 12 January 1967, in M1090: R. Buckminster Fuller Papers, Series 2, Box 153, Folder 1, SUL. On Shōriki distancing himself, see Sadao, 'Buckminster Fuller's', p. 14.
} 
seems to have come out in August $1967 .{ }^{54}$ However, by then Fuller had become fully aware of Shōriki's lack of interest, had stopped associating the project with Tokyo Bay, and had become more interested in American coastal cities.

Where Tange used large physical infrastructures, such as highways, to create transportation and communication networks, Fuller aimed to disconnect from them as much as possible. From the late 1920s onwards Fuller's designs for new forms of dwellings had focused on autonomy. One of his central aims was to minimize the need for physical infrastructures-in a protoecomodernist sense-resulting in a strongly reduced need for construction space, landscaping, and attendant environmental degradation. Fuller focused mainly on air, and later also on water, instead of highways and railways using solid, horizontal space. ${ }^{55}$ In his cybernetic designs, telegraph and phone cables and so on were replaced with radio waves. Urban sewage systems and power grids were removed in favour of service systems of plumbing, rainwater collection, and power generation in individual dwelling units. Moreover, the dwelling units were given as much mobility as possible, allowing their centralized mass production, followed by delivery and, if necessary, relocation. This mobility was supposed to drastically reduce construction costs compared to individual on-site construction. The geodesic domes that he became famous for in the 1950s could be air-delivered, while his 'floating city' design would, after construction in a shipyard, use the mobility that marine regions also gave ships and floating oil platforms. ${ }^{56}$ In this regard, floating oil platforms, built since the early 1960s, had inspirational value: with increasing distance from the coastline, they were mainly connected through radio waves and helicopters as well as ships.

The mobility of dwellings served to make the idea of permanent settlements obsolete, shifting them towards being ephemeral or 'instant', and operated and guided by communication networks. Such dwelling characteristics attracted massive public attention during the 1960s, when space researchers began to design structures for crewed expeditions into outer space, resulting in the first moon landing in 1969. As Peder Anker emphasized, such designs for American space shuttles and stations, termed 'cabin ecologies' by astronauts, could not rely on physical infrastructures. ${ }^{57}$ Instead, they had to operate as communication network-connected, autonomous dwellings, featuring

\footnotetext{
${ }^{54}$ On Fuller mentioning the idea in the American media, see Buckminster Fuller, Dear Mr. Shibata, 25 January 1967, in M1090: R. Buckminster Fuller Papers, Series 2, Box 153, Folder 8, SUL; 'An Expo Named Buckminster Fuller', New York Times, 23 April 1967, pp. 33, 134, 138, 140, 144. On the brief Asahi Shinbun report, see 'Tōkyō-wan ni "ukabu toshi"' ['Floating City' in Tokyo Bay], Asahi Shinbun, 27 August 1967, morning edition, p. 15. On the tower, see Bimonthly Report, 2 March 1968, in M1090: R. Buckminster Fuller Papers, Series 2, Box 166, Folder 8, SUL, and their previous reports.

${ }^{55}$ See, for example, Buckminster Fuller, 'Report on the Geosocial Revolution', Saturday Review, 16 September 1967, pp. 31-33, 63, here: p. 32.

${ }^{56}$ Pawley, Buckminster Fuller, pp. 115-146; Federico Neder, Fuller Houses. R. Buckminster Fuller's Dymaxion Dwellings and Other Domestic Adventures (Zurich: Lars Müller Publishers, 2008), pp. 17-19.

${ }^{57}$ Peder Anker, 'The Ecological Colonization of Space', Environmental History 10, no. 2 (2005), pp. 239-268, here pp. 241-244.
} 
automated power and water service systems. Solar energy generation experienced a first research boom. In that sense, in an attempt to improve the global shelter problem of the 1960s, Fuller's Tokyo Bay proposal was the maritime equivalent of a huge space shuttle or space station that was supposed to operate largely autonomously.

Fuller's proto-ecomodernist aim for the service systems to be autonomous strongly focused on using technology to allow industrial growth while reducing pressure on ecosystems, here in the sense of a limited need to extract freshwater and to exploit and burn fossil fuels for electricity generation. This autonomy then also contributed to the mobility of the megastructure that would be disconnected from physical grids. To provide electricity for the structure, Fuller foresaw the integration of a small nuclear reactor. ${ }^{58}$ Considering the Japanese context, this decision was hardly unexpected. Shōriki, sometimes called the 'father' of nuclear energy in Japan, had imported nuclear reactor technology to Japan during his term as director of the newly founded Atomic Energy Commission (Genshiryokuiinkai) in 1956. In his MIT seminar in 1959 Tange had already described nuclear reactors as a source of cheap and almost limitless energy. By 1966 and early 1967, a first Japanese nuclear reactor had produced electricity and two more were under construction. Fuller's proposal also appealed to the broader political understanding of the peaceful use of nuclear energy which, as an advanced technological solution, would satisfy a rising share of the Japanese high growth economy's strongly increasing energy demands. In the United States, the second part of the 1960 s also saw a nuclear power boom. Utility companies had underestimated the rate at which electricity consumption would rise during these years and therefore increased their estimates for the 1970s, resulting in mass-ordering of nuclear plants. ${ }^{59}$ This boom certainly further influenced Fuller. Nuclear reactors being used to power aircraft carriers and submarines also meant that the general idea of installing one on an offshore megastructure appeared to be a feasible approach. Fuller therefore was able to propose a second benefit of the reactor by copying aircraft carrier technology: it could be used for desalinating Bay water, providing the megastructure with an autonomous freshwater service system. ${ }^{60}$ The presence of a nuclear reactor, meaning density in energy generation, in a densely populated megastructure thus combined two proto-ecomodernist ideas. These ideas were located in a scenario that still operated within a positive public image of nuclear energy as a pillar of the Japanese economy and consumer society. However, in the sense of the 'not in my backyard' syndrome, the placement of nuclear reactors was associated more with rural areas, rather than major cities like Tokyo and its bay. The Tokyo Bay location would therefore have caused resistance to

\footnotetext{
${ }^{58}$ R. Buckminster Fuller, 'City of the Future', Playboy 15, no. 1 (1968), pp. 166-168, 228-230, here: p. 230. Fuller, regularly focusing on popular outreach and not on scientific journals, therefore also submitted articles to Playboy magazine's article section.

${ }^{59}$ Robert D. Lifset, 'Nuclear Power in America: The Story of a Failed Energy Transition', Environmental History 24, no. 3 (2019), pp. 524-533.

${ }^{60}$ Fuller, 'City', p. 230.
} 
Fuller's proposal, as a similar event which took place around that time showed. During spring and summer 1967, the city administration of Yokohama strongly opposed the construction of special port facilities for an experimental, nuclear-powered merchant ship, the Mutsu. Among the reasons was the very limited self-cleansing ability of the Bay. In case of an accidental reactor leak leading to a release of radioactive cooling water, the Bay's outbound tides would not quickly flush out the pollution into the ocean. ${ }^{61}$ Logically, the same concerns would arise in the case of a nuclear-powered floating settlement in the Bay, but by then Fuller had shifted focus to American coastal cities. In the process, he substantially reduced the size of his design and also removed the reactor that he had opportunistically added. Slightly later, he returned to advocating renewable sources like solar, wind, tidal, and hydropower instead of exhaustible nuclear energy and fossil fuels. ${ }^{62}$

In terms of autonomy and mobility, one can understand Fuller's design not only as related to outer space but also as one of the amphibious transformation's alternatives to large hydroelectric dams. Such dams were tools for storing freshwater, regulating its availability all year round instead of relying on natural fluctuations, and generating electricity. However, the average large hydroelectric dam had a substantial ecological footprint through terrestrializing a huge space. Such dams also reduced sediment flux from upstream that often could not then compensate for erosion, meaning that many affected river deltas are sinking more rapidly than sea levels are rising. ${ }^{63}$ A large dam's removal would be extremely complicated and costly, while Fuller's design had a mobile ecological footprint. Mobility also strongly increased sustainability in the sense that the structure's full lifespan could be utilized, being relocated instead of demolished if it was not needed anymore in a certain place, similar to a floating offshore oil platform (and unlike terrestrial buildings). ${ }^{64}$

Fuller's floating tetrahedral megastructure was, as a cybernetic environmental control machine, supposed to urbanize the Bay by adapting to unstable aquatic surfaces. In addition to the horizontal mobility that Fuller's floating structure gained, he emphasized the need for vertical mobility and an earthquake-proof design. A structure floating on the Bay's water, which was therefore very resilient to the seismic waves of tremors compared to landbased structures, would solve Japan's earthquake problem, which had

\footnotetext{
61 'Genshiryokusen boko wa anzen ka [How about the Safety of a Nuclear-Powered Ship's Home Port?]', Asahi Shinbun, morning edition, 20 July 1967, p. 19. See also Toshihiro Higuchi, 'Mutsu Adrift: A Nuclear Ship, Scallop Growers, and the Inescapable Ecologies of Mutsu Bay', in Oceanic Japan: The Archipelago in Pacific and Global History, (eds) Nadin Heé, Stefan Huebner, Ian J. Miller and William Tsutsui (Honolulu: University of Hawai'i Press, in press).

${ }^{62}$ R. Buckminster Fuller, Operating Manual for Spaceship Earth (New York: Simon and Schuster, 1970; paperback reprint of 1969), pp. 123-124.

${ }^{63}$ James P. M. Syvitski and Albert Kettner, 'Sediment Flux and the Anthropocene', Philosophical Transactions of the Royal Society A 369, no. 1938 (2011), pp. 957-975.

${ }^{64}$ On this point in regard to more recent floating homes, see also Koen Olthuis and David Keuning, Float! Building on Water to Combat Urban Congestion and Climate Change (Amsterdam: Frame, 2010), pp. 207-208.
} 
destroyed large parts of Tokyo in 1923 (and would contribute to the Fukushima disaster in 2011). Fuller even recommended that further tetrahedral megastructures, if set up on land, should be floated in artificial lakes to provide them with the same earthquake resilience. ${ }^{65}$ Tange, in contrast, given his plan to use reinforced concrete and partially submerge most piers, apparently did not worry about the impact of strong earthquakes-or at least did not discuss them, although the breakdown of his elevated structures conjures up the image of millions of human fatalities. Fuller's adaptation to the Bay's waters therefore was not just an attempt to gain construction space for some kind of high-rise that could be erected on land as well. Vertical mobility and resilience to water level change, caused by regular tides, floods, or tremor waves, as well as (then unknown) sea level rise, should be understood as an important driving force of the amphibious transformation. Consequently, Fuller's adaptation to the marine surface is a noteworthy difference to Tange Lab's 'Plan', based on elevation (but with a similarity to Kikutake's utopian proposals).

In terms of growth and adaptation, Fuller saw a regular tetrahedron as the most efficient shape for his floating, terraced megastructure. He mentioned its ability to replicate biological growth or, as one of Shōriki's staff members summed it up, the megastructure would be 'symmetrically growable as are biological systems' ${ }^{66}$ After all, a tetrahedral shape allows symmetrical growth by additions to any of its faces without losing its shape in the process. Fuller did not explain how such growth could be efficiently implemented in the case of an already existing megastructure. However, his design did provide flexibility in terms of up- or downscaling the size during the planning stage. Fuller chose the shape due to the structural efficiency of a regular tetrahedron when its size was confronted with the forces of gravity and wind. For adaptation to marine surfaces, even more important was that its structural efficiency, in the sense of its centre of gravity and the upward force its weight generated, made it float securely. The tetrahedral shape also geometrically maximized the megastructure's surface space on which individual dwelling units were to be set up, meaning high population density on a marine surface. ${ }^{67}$

Fuller's understanding of individual dwelling units further illustrates his aim of mobility. In his design, network-connected people would be liberated from the immobilizing heritage of settled agriculture. His suggestion was to grant, on each terrace of the megastructure, 2,000 square feet per dwelling unit. Dwelling units would be provided by the inhabitants in the form of mobile and technologically advanced trailer cars or house boats. ${ }^{68}$ These two suggested forms of dwelling followed Fuller's general ideas about the necessity of using technologically advanced designs as a tool to grant people freedom. In the Japanese post-war and Cold War context, Fuller's ideas went even further

\footnotetext{
${ }^{65}$ Fuller, 'City', pp. 229-230.

${ }^{66}$ Hidetoshi Shibata, Dear Dr. Fuller.

67 'Man with a Chronofile', Saturday Review, 1 April 1967, pp. 14-18, here: p. 16. See also the later explanations in R. Buckminster Fuller, Synergetics. Explorations in the Geometry of Thinking, Vol. 1 (New York: MacMillan, 1975), p. 341.

${ }^{68}$ Fuller, 'City', p. 229.
} 
than Tange's understanding that growing communication networks were essential to create a liberal society. The land reform implemented during the Allied occupation (1945-1952) roughly two decades earlier had liberated many farming families from structures of dependence on landowners. Industrialization also had contributed to immobility by concentrating large numbers of workers in urban industrial spaces. Individual workers were quite mobile in post-war Japan. ${ }^{69}$ However, collectively, like anywhere else, they still had to live within a reasonable distance of factories and other workspaces that required their personal presence. Fuller (like Tange) focused on Japan as a post-industrial society. He saw no particular need for landownership or workplace-related immobility anymore, considering that homo sapiens had evolved as a nomad. ${ }^{70}$ Quite obviously, Fuller's main driving force in what he saw as a cybernetics-driven megatrend was the new ability of people to engage in various (non-agricultural, non-industrial) occupations or activities while physically being located at whatever place was connected to global networks. ${ }^{71}$ One should add that such connectivity grew rapidly during the following decades, which included oceanic places. For Fuller, freedom for inhabitants thus meant that dwelling designs had to enable people to move their homes to where they wanted to live.

\section{Conclusion: the cybernetic origins of ecomodernist marine urbanization}

Tange Lab's and Fuller's cybernetic ideas and practices of growth, adaptation, mobility, and autonomy served to technologically reduce the ecological footprint of urbanization while addressing Tokyo's terrestrial urban sprawl problems. Such technological adaptation was based on replicating and utilizing what they acknowledged as the new scientific authority of hundreds of millions of years of evolution of biological communication systems. Communication network connectivity became the foundation of the amphibious transformation of Earth's surface, which resulted in marine urbanization proposals and numerous other unconventional offshore settlements. The network expansion also caused the current age of hyper-connectivity, where satellite and other internet technologies allow permanent audio-visual connectedness, meaning that one person's smartphone or laptop can serve as the mobile extension of another person's eyes, ears, and nervous system, increasingly even offshore. Based on this cybernetic connectivity, the aims of technologically reducing urbanization's ecological footprint, adaptation to unstable aquatic spaces, and resilience to disasters then shaped the ecomodernist strand in marine urbanization that focuses on urbanizing and industrializing a significant (arbitrarily defined) part of the ocean.

\footnotetext{
${ }^{69}$ Andrew Gordon, The Evolution of Labor Relations in Japan: Heavy Industry, 1853-1955 (Cambridge, MA: Harvard University Press, 1985), p. 2.

${ }^{70}$ Buckminster Fuller, 'Letter to Doxiadis', Main Currents in Modern Thought 25 (March-April 1969), pp. 87-97, here: p. 97.

${ }^{71}$ Fuller, 'City', p. 228.
} 
Such marine urbanization is a topic that will shape the twenty-first century. In addition to emphasizing the lack of accessible data, a recent study has estimated that in 2018 human-built structures-ports, aquaculture, oil rigs, wind turbines, breakwaters, and so on)-have claimed a minimum of 32,000 kilometres $^{2}$ of seafloor, more than half of it in East Asia. Their impact modified 1 to 3.4 million kilometres ${ }^{2}$ of ocean space or about 1.5 per cent of global Exclusive Economic Zones-a size comparable to the global extent of urban land. By 2028, the impact is expected to increase by 50 to 70 per cent. ${ }^{72}$ An ecomodernist 'sustainable floating city' as a solution to reducing the human ecological footprint on the ocean can thus be debated. However, it also needs to be contrasted to the footprints of, for example, the continuing ocean sprawl of other human-built structures, heavy fuel oil-burning ships or, on land, large hydroelectric dams.

There is no evidence that Tange or Fuller considered their marine urbanization designs to be utopian or technically unfeasible. This distinction is important. As Dutch amphibious architect Koen Olthuis emphasized in 2010, utopian amphibious or floating proposals 'at the margin of architecture production' reduced the credibility of feasible ideas. ${ }^{73}$ Without question, Tange Lab's and Fuller's first proposals were, due to their size and shift to aquatic surfaces, highly provocative to attract public attention. They hence received, as part of the global cybernetics boom, numerous contemporary responses, some very critical, in both Japanese and multiple European languages. ${ }^{74}$ In Tange's case, ironically, what began with the cybernetic analogy of a tree received strong criticism regarding its lack of flexibility in design theorist Christopher Alexander's well-known article titled 'A city is not a tree' (1965). ${ }^{75}$ Moreover, feasibility did not automatically mean efficiency, considering that their designs were among the first of their kind. Aesthetically, in my view, they were debatable. Altogether, the actual implementation of their designs would have necessitated further, far more detailed plans as well as a budget- and construction regulation-related substantial size reduction. For example, the 'Plan' strongly inspired the creation of Amsterdam's expansion district IJburg (1997-present), albeit in a scaled-down form. Fuller's modified and strongly scaled-down version, 'Triton City', later proposed for American harbour waters, passed US Navy stability calculations in 1968 and contributed to studies at the University of Hawai'i and the construction of Kikutake's 'Aquapolis', the 'floating city' hosting the Japanese exhibition at the 1975

\footnotetext{
${ }^{72}$ Ana Bugnot et al., 'Current and Projected Global Extent of Marine Built Structures', Nature Sustainability 4 (2021), pp. 33-41.

${ }^{73}$ Olthuis and Keuning, Float!, p. 284.

${ }^{74}$ The following is a very short and arbitrary overview of contemporary articles in three languages other than Japanese: Peter Smithson, 'Reflections on Kenzo Tange's Tokyo Bay Plan', Architectural Design 34 (1964), pp. 479-480; Paul Maymont, 'Le fantastique concrétisé', L'architecture d'aujourd'hui 115 (1964), pp. 30-36; H.-U. Meyer, 'Tokyo-Plan 1960-2000', Bauen + Wohnen 26, no. 10 (1972), pp. 476-478; Simon Klinger, 'Cities on the Sea', Engineering 207 (1969), pp. 422-425. For more proposals, see Sandra Kaji-o'grady and Peter Raisbeck, 'Prototype Cities in the Sea', The Journal of Architecture 10, no. 4 (2005), pp. 443-461.

${ }^{75}$ Christopher Alexander, 'A City Is Not a Tree', Design 206 (1966), pp. 46-55.
} 
International Ocean Exposition in Okinawa. ${ }^{76}$ However, the terrestrial mindset among Japanese civil servants and many others focused on the control and removal of water instead. In combination with a lesser contemporary concern for limiting the ecological footprint of urbanization, the terrestrial mindset shaped their decisions regarding urban planning and regional development. The same terrestrial mindset, while aware of a global spree of large hydroelectric dam projects and the corresponding high dam technology, generally judged marine urbanization projects to be utopian or dangerous. What Tokyo Bay nonetheless created is an intellectual strand that, I emphasize, turned Tange and Fuller into founding fathers of ecomodernist, large-scale marine urbanization designs which, modified during the following decades, have shaped this adaptation approach. ${ }^{77}$

Fuller's space station-like autonomy and mobility ideas, which went beyond Tange Lab's, emphasized that communication network access was the foundation of the amphibious transformation and also of his particular marine urbanization proposal. Marine surfaces became places of global urbanization, defined by network connectivity that would eliminate the previous remoteness of such spaces and enable people to engage in forms of work that did not necessitate their physical presence at a certain place, such as agricultural sites or factories. Fuller also advanced the mobility of the megastructure, more than Tange Lab's elevated plan could have done, since his design focused on floatation. Since Fuller, the cybernetics ideas and practices hence were supposed to technologically create ephemeral or 'instant' forms of urbanization with the corresponding reduced ecological footprint-an ecomodernist scheme that one can again contrast to the impact of a large hydroelectric dam as a

${ }^{76}$ On Tange's PR campaign, see Lin, Kenzo Tange, pp. 145-146. On IJburg, see Olthuis and Keuning, Float!, p. 276. For the US Navy study, see Robert A. Frosch, Dear Mr. Haar, 22 November 1968, in M1090: R. Buckminster Fuller Papers, Series 2, Box 178, Folder 7, SUL. On Hawai'i and Aquapolis, see Stefan Huebner, 'Tackling Climate Change, Air Pollution, and Ecosystem Destruction: How US-Japanese Ocean Industrialization and the Metabolist Movement's Global Legacy Shaped Environmental Thought (c. 1950s-Present)', Environmental History 25, no. 1 (2020), pp. 35-61.

${ }^{77}$ A short overview of current marine urbanization publications referring to Tange or Fuller include: Olthuis and Keuning, Float!, in particular pp. 273-277; C. M. Wang and B. T. Wang, 'Great Ideas Float on Top', in Large Floating Structures. Technological Advances, (eds) C. M. Wang and B. T. Wang (Singapore: Springer Singapore, 2015), pp. 1-36; Joe Quirk and Patri Friedman, Seasteading. How Floating Nations Will Restore the Environment, Enrich the Poor, Cure the Sick, and Liberate Humanity from Politicians (New York: Free Press, 2017). A short overview of recent news publications include: Tom Metcalfe, 'This Floating City Concept Is One Way to Cope with Climate Change', https://www.nbcnews.com/mach/science/floating-city-concept-one-way-cope-climatechange-ncna995081, [accessed 15 June 2021]; Lucy Wang, 'It's an Unsinkable Idea', https://www. anthropocenemagazine.org/2020/07/its-an-unsinkable-idea/, [accessed 15 June 2021]; Andrew Revkin, 'Floating Cities Could Ease the World's Housing Crunch, the UN Says', https://www.national geographic.com/environment/2019/04/floating-cities-could-ease-global-housing-crunch-says-un/, [accessed 15 June 2021]; Stefan Huebner, 'Climate Action: Sustainable Floating Cities', https://archiveyaleglobal.yale.edu/content/climate-action-sustainable-floating-cities; Amanda K. Hurley, 'Floating Cities Aren't the Answer to Climate Change', https://www.bloomberg.com/news/articles/2019-0410/floating-cities-won-t-save-us-from-climate-change, [accessed 15 June 2021]. See also Huebner, 'Tackling Climate Change'; Wigley, Buckminster Fuller, pp. 279-329; Kaji-o'grady and Raisbeck, 'Prototype'. 
representative not of the amphibious transformation but of ubiquitous terrestrialization-focused urbanization and industrial development. Applying mobility also to individual dwelling units, which were to be based on the mobile megastructure, then enabled him to propose even stronger modularization, since his modular dwelling units would be able to be transferred between floating megastructures. Over the following decades, this modularization of floating units was further contemplated. Later designs, such as those of the Bjarke Ingels Group related to the UN's 'sustainable floating cities' roundtable, utilized only floating modular units that, together, formed a megastructure. ${ }^{78}$ Amina Mohammed's roundtable speech can serve as an example regarding autonomy. Similar to Fuller's case, autonomy meant no need for physical grid connections for outside electricity intakes and no fossil fuel-based electricity generation. In her speech, solar power served industrial and economic development, while mitigating climate change and environmental degradation. Mohammed's speech and the Bjarke Ingels Group's design therefore are both ecomodernist applications of Tange Lab's and Fuller's large-scale marine urbanization ideas of growth, adaptation, mobility, and autonomy. ${ }^{79}$

What this article emphasizes is that climate change adaptation and mitigation approaches should not be evaluated exclusively within a terrestrial mindset. This mindset, which greatly intensified in Asia during the twentieth century, discouraged consideration of Tange Lab's and Fuller's designs, flawed as they were as very early contemplations about amphibious and floating urbanization approaches. Urbanization's continuing vulnerability to floods, subsidence, and other disasters, which an exclusive focus on controlling and removing water is unable to prevent, and the anthropogenic rise of sea levels that will intensify their impact, are problems that cannot be fully dealt with within such a terrestrial mindset. If adaptation or mitigation approaches are exclusively evaluated within such a mindset, then terrestrialization-associated with high dam technology, seawalls, or land reclamation and resulting in potentially huge ecological footprints that include river delta sinking-continues to provide the framework for any disaster prevention. Adaptation and mitigation approaches then stay within this mindset of water removal and control attempts instead of increasing resilience through elevation or floatation. After all, in this terrestrial mindset, amphibious or floating approaches are easily ignored, outright denied, marginalized, or branded utopian, even though Earth's surface has continued to experience an amphibious transformation through (unconventional) settlements as well as advances in amphibious and floating architecture. In that sense, Tokyo Bay emphasizes the important role that Asian cities have played in shaping global contemplations about urban trends related to urbanization's growing impact on the ocean.

Acknowledgements. I would like to thank the Asia Research Institute, National University of Singapore; the Harvard University Asia Center; the Social Science Research Council (SSRC) New York City, and its Transregional Research Junior Scholar Fellowship Program; the Fulbright

\footnotetext{
${ }^{78}$ United Nations, 'Sustainable Floating Cities'; Bjarke Ingels Group, 'Sustainable Floating City', https://big.dk/\#projects-sfc, [accessed 15 June 2021].

${ }^{79}$ Ibid.
} 
Commission; the Woodrow Wilson International Center for Scholars; the German Historical Institute Washington, DC; and the Social Science Research Council (SSRC), Singapore. I am also grateful to my friends and colleagues who provided valuable comments at institutional events at the National University of Singapore, Harvard University, and other places as well as international workshops and conferences. The staff of Harvard University's Frances Loeb Library, Stanford University libraries, and many other institutions were very supportive.

Cite this article: Huebner, Stefan. 2022. 'Earth's Amphibious Transformation: Tange Kenzo, Buckminster Fuller, and marine urbanization in global environmental thought (1950s-present)'. Modern Asian Studies 56 (4), pp. 1053-1082. https://doi.org/10.1017/S0026749X21000251 